\title{
PENGARUH KETERSEDIAAN SARANA PENDIDIKAN TERHADAP ANGKA PARTISIPASI KASAR (APK) DI KOTA CILEGON
}

\author{
Hesti Pudyastuti ${ }^{1}$ Euis Mulyaningsih ${ }^{2}$ \\ ${ }^{1}$ Fungsional Perencana Ahli Madya, Bappeda Kota Cilegon \\ Email: hezpudya@gmail.com \\ ${ }^{2}$ Widyaiswara Ahli Madya, BPSDM Provinsi Banten \\ Email: euismulyaningsih@gmail.com
}

\begin{abstract}
This study aims to determine the percentage of the availability of educational facilities in the city of Cilegon, and its effect on the Gross Enrollment Rate (APK). The research method is carried out using a quantitative approach, with the analysis technique is using a simple linear regression analysis. The results of this study indicate that the availability of educational facilities and the APK for kindergarten education in Cilegon City has a moderate effect, with a regression coefficient $R^{2}$ of 0.482 , the availability of educational facilities and the APK for primary school education in Cilegon City has a significant effect, with a regression coefficient value. $R^{2}$ is 0.854 , while the availability of educational facilities and the APK for junior high school education in Cilegon City has no significant relationship, with a regression coefficient $R^{2}$ of 0.124 .
\end{abstract}

Keywords : Educational fasilities, Gross Partisipation.

Abstrak. Penelitian ini bertujuan untuk mengetahui Persentase ketersediaan sarana pendidikan di Kota Cilegon, serta pengaruhnya terhadap Angka Partisipasi Kasar (APK). Metode penelitian dilakukan dengan menggunakan pendekatan kuantitatif, dengan teknik analisis menggunakan analisis regresi linear sederhana. Hasil penelitian yang diperoleh menunjukkan bahwa ketersediaan sarana pendidikan dan APK jenjang pendidikan TK di Kota Cilegon memiliki pengaruh yang moderat, dengan nilai koefisien regresi $R^{2}$ sebesar 0,482 , ketersediaan sarana pendidikan terhadap APK jenjang pendidikan SD di Kota Cilegon memiliki pengaruh yang signifikan, dengan nilai koefisien regresi $R^{2}$ sebesar 0,854 sedangkan ketersediaan sarana pendidikan terhadap APK jenjang pendidikan SMP di Kota Cilegon tidak memiliki hubungan yang signifikan, dengan nilai koefisien regresi $R^{2}$ sebesar 0,124 .

Kata Kunci : Sarana Pendidikan, Partisipasi Kasar.

\section{PENDAHULUAN}

Pendidikan memberikan pengaruh yang besar dalam peningkatan kualitas manusia. Penyediaan sarana dan prasarana pendidikan menjadi kewajiban pemerintah dalam pemenuhan pelayanan dasar. Dengan ketersediaan sarana dan prasarana pendidikan yang memadai dan berkualitas, diharapkan angka partisipasi sekolah juga meningkat, sebagaimana Sugarda (2018) menjelaskan bahwa peningkatan akses dan mutu sarana dan prasarana pendidikan dapat meningkatkan penuntasan wajib belajar 9 tahun.

Angka Partisipasi Kasar (APK) merupakan perbandingan antara jumlah seluruh anak yang bersekolah dalam jenjang pendidikan tertentu dibagi dengan jumlah anak dalam rentang usia tertentu hal ini disampaikan juga oleh Sugarda (2018), Kurnia, dkk (2015), serta Istiqomah, dkk (2018). Sedangkan menurut Badan Pusat Statistik (BPS), APK ini dapat digunakan untuk mengukur tingkat partisipasi penduduk dalam suatu jenjang pendidikan, serta seberapa besar kapasitas sarana pendidikan dapat menampung siswa pada kelompok sekolah tertentu. Oleh karena itu, penulis 
mencoba menganalisis sejauh mana hubungan antara ketersediaan sarana pendidikan terhadap APK Tahun 2019 di Kota Cilegon.

Perhitungan ketersediaan sarana pendidikan berdasarkan SNI-03-1733-2004 Tentang Tata cara Perencanaan Lingkungan Permukiman di Perkotaan, mempersyaratkan batasan radius pencapaian gedung sekolah TK maksimal adalah 500 meter, radius pencapaian gedung sekolah SD dan SMP dibatasi maksimal 1 kilometer. Sedangkan jarak tempuh ke sekolah SMA dibatasi maksimal 3 kilometer. Adapun standar jumlah siswa dalam 1 kelas untuk TK dan SD dibatasi antara 25-30 murid, sedangkan siswa untuk SMP dan SMA dalam 1 kelas dibatasi maksimal sebanyak 40 murid. Standar perhitungan ini sedikit berbeda dengan standar yang ditetapkan dalam Permendikbud Nomor 23 Tahun 2013 Tentang Perubahan Atas Peraturan Menteri Pendidikan Nasional Nomor 15 Tahun 2010 Tentang Standar Pelayanan Minimal Pendidikan Dasar Di Kabupaten/Kota, dimana untuk sekolah SD batas radius pencapaian dibatasi maksimal 1 kilometer, dan SMP maksimal 3 kilometer. Jumlah maksimal siswa dalam 1 kelas untuk SD sebanyak 32 orang, sedangkan untuk SMP sebanyak 36 orang. Dalam peraturan ini tidak mengatur persyaratan untuk sekolah TK dan SMA.

Melati (2018) pernah melakukan penelitian serupa dengan menganalisis hubungan ketersediaan gedung sekolah SMA/Sederajat dengan Angka Partisipasi Kasar (APK) di Kabupaten Wonosobo menggunakan metode chi-square dan mendapatkan hasil adanya pengaruh yang signifikan antara ketersediaan gedung SMA/sederajat berdasarkan jumlah penduduk terhadap APK. Penelitian mengenai APK juga pernah dilakukan oleh Dini (2017) dengan menganalisis pengaruh partisipasi pendidikan terhadap persentase penduduk miskin, dengan hasil hipotesis menyatakan bahwa APK dengan jumlah penduduk miskin di DKI Jakarta tahun 2009 - 2013 tidak terdapat pengaruh yang signifikan.

Penelitian ini sepanjang pengetahuan penulis belum pernah dilakukan di Kota Cilegon, sehingga penulis tertarik untuk melakukan analisis ini dengan harapan dapat mengetahui seberapa besar ketersediaan sarana pendidikan di Kota Cilegon dan seberapa besar pengaruhnya terhadap APK. Dengan penelitian ini, diharapkan dapat menjadi rujukan bagi Pemerintah Kota Cilegon untuk menentukan lokasi yang tepat dalam pembangunan sarana pendidikan, serta melakukan upaya dalam meningkatkan APK. Namun dalam penelitian ini, penulis belum memisahkan ketersediaan sekolah negeri dan swasta serta belum memperhitungkan kualitas sarana dan prasarana dimasingmasing sekolah, sehingga belum bisa menunjukkan sebaran sekolah yang berkualitas di Kota Cilegon.

\section{METODE PENELITIAN}

Penelitian ini disajikan dengan menggunakan analisis deskriptif. Ashari, dkk (2017) dan Putra (2012) menjelaskan bahwa proses mengeksplorasi data mentah menjadi informasi dalam bentuk table atau grafik yang mudah dipahami merupakan alasan atas penggunaan analisis deskriptif ini. Analisis terhadap kebutuhan dan ketersediaan sarana pendidikan di Kota Cilegon yang berupa gedung sekolah TK, SD, SMP dan SMA dilakukan dengan membandingkan ketersediaan sarana pendidikan yang sudah ada berdasarkan data dari Kota Cilegon Dalam Angka Tahun 2020 (BPS) dan menghitung kebutuhan ideal sarana pendidikan berdasarkan SNI 03-1733-2004 Tentang Tata cara Perencanaan Lingkungan Permukiman di Perkotaan.

Dalam perhitungan ini juga dilakukan pembandingan dengan kebutuhan riil yang dihitung berdasarkan kebutuhan terhadap anak usia sekolah tertentu yang belum mengenyam bangku sekolah. Sumber APK menggunakan data dari Profil Dinas Pendidikan (2019). Namun dikarenakan data APK tingkat SMA tidak tersedia, maka analisis pengaruh ketersediaan sarana pendidikan di Kota Cilegon hanya dilakukan untuk jenjang TK, SD dan SMP.

Adapun standar perhitungan ketersediaan sarana pendidikan berdasarkan SNI-03-1733-2004 adalah sebagaimana dalam tabel 1 berikut : 
Tabel 1. Standar Perhitungan Sarana Pendidikan

\begin{tabular}{|c|c|c|c|c|c|c|}
\hline \multirow[b]{2}{*}{ No. } & \multirow[b]{2}{*}{$\begin{array}{l}\text { Jenis } \\
\text { Sarana }\end{array}$} & \multirow[b]{2}{*}{$\begin{array}{c}\text { Jumlah } \\
\text { penduduk } \\
\text { pendukung } \\
\text { (jiwa) }\end{array}$} & \multicolumn{2}{|c|}{$\begin{array}{l}\text { Kebutuhan Per } \\
\text { Satuan Sarana }\end{array}$} & \multirow[b]{2}{*}{$\begin{array}{l}\text { Standard } \\
\text { (m2/jiwa) }\end{array}$} & \multirow{2}{*}{$\begin{array}{c}\text { Kriteria } \\
\begin{array}{c}\text { Radius } \\
\text { pencapaian }\end{array}\end{array}$} \\
\hline & & & $\begin{array}{l}\text { Luas Lantai } \\
\text { Min (m2) }\end{array}$ & $\begin{array}{c}\text { Luas Lahan } \\
\text { Min (m2) }\end{array}$ & & \\
\hline 1. & $\begin{array}{l}\text { Taman } \\
\text { Kanak- } \\
\text { Kanak }\end{array}$ & 1.250 & $\begin{array}{c}216 \\
\text { Termasuk } \\
\text { rumah } \\
\text { Penjaga (36 } \\
\text { m2) }\end{array}$ & 500 & $\begin{array}{c}0,28 \\
\mathrm{~m}^{2} / \mathrm{jiwa}\end{array}$ & $500 \mathrm{~m}^{\prime}$ \\
\hline 2. & $\begin{array}{l}\text { Sekolah } \\
\text { Dasar }\end{array}$ & 1.600 & 633 & 2.000 & 1,25 & $1.000 \mathrm{~m}^{\prime}$ \\
\hline 3. & SMP & 4.800 & 2.282 & 9.000 & 1,88 & $1.000 \mathrm{~m}^{\prime}$ \\
\hline 4 & SMA/SMK & 4.800 & 3.835 & 12.500 & 2,6 & $3.000 \mathrm{~m}^{\prime}$ \\
\hline
\end{tabular}

Analisis pengaruh antara kedua variabel yaitu Persentase ketersediaan sarana pendidikan dan APK dilakukan dengan menggunakan Analisis Regresi Linear Sederhana. Analisis regresi linear sederhana adalah analisis regresi yang digunakan untuk memprediksi satu variabel tergantung berdasarkan pada satu variabel bebas. Penggunaan analisis ini dimaksudkan agar dapat mengukur kekuatan hubungan antara dua variable (Imran, 2018), serta dapat memprediksi kondisi selanjutnya, memberikan gambaran yang lebih jelas, melakukan control, dan mendapatkan cara untuk proses penerapannya (Faisol dkk, 2016). Analisis regresi linear sederhana dapat dinyatakan dengan hubungan persamaan regresi: $Y=\alpha+b X$

dimana:

$Y=$ Subyek dalam variabel dependen yang diprediksikan

$\alpha=$ Harga $\mathrm{Y}$ ketika harga $\mathrm{X}=0$ (harga konstan)

$\mathrm{b}$ = Angka arah atau koefisien regresi, yang menunjukkan angka peningkatan ataupun penurunan variabel dependen yang didasarkan pada perubahan variabel independen. Bila $(+)$ arah garis naik, dan bila (-) arah garis turun.

$\mathrm{X}=$ Subyek pada variabel independen yang mempunyai nilai tertentu.

Selain itu harga $\alpha$ dan $b$ dapat dicari dengan menggunakan rumus sebagai berikut :

$$
\begin{aligned}
& \alpha=(\Sigma Y i)(\Sigma X i 2)-(\Sigma X i)(\Sigma X i Y i) n \Sigma X i 2-(\Sigma X i) 2 \\
& b=n \Sigma X i Y i-(\Sigma X i)(\Sigma Y i) n \Sigma X i 2-(\Sigma X i) 2
\end{aligned}
$$

Hipotesis yang digunakan:

$H 0: \beta=0$ (Tidak ada hubungan linear antara variabel independen dengan dependen), artinya persamaan regresi tidak berarti.

$H 0: \beta \neq 0$ (Ada hubungan linear antara variabel independen dengan dependen), artinya persamaan regresi berarti.

\section{HASIL PENELITIAN DAN PEMBAHASAN}

\section{a. Analisis Kebutuhan Sarana Pendidikan Berdasarkan Jumlah Penduduk (SNI 03-1733-2004)}

Analisis kebutuhan sarana pendidikan di Kota Cilegon yang meliputi gedung sekolah TK, SD, SMP dan SMA menurut SNI 03-1733-2004, dihitung berdasarkan jumlah penduduk, dengan hasil sebagaimana dalam Tabel 2 . 
Tabel 2 Kebutuhan dan Ketersediaan Sarana Pendidikan

\begin{tabular}{|c|c|c|c|c|c|c|c|c|}
\hline \multirow{2}{*}{ KECAMATAN } & \multicolumn{2}{|c|}{ TK } & \multicolumn{2}{|c|}{ SD } & \multicolumn{2}{|c|}{ SMP } & \multicolumn{2}{|c|}{ SMA } \\
\hline & KEBUTUHAN & KETERSEDIAAN & KEBUTUHAN & KETERSEDIAAN & KEBUTUHAN & KETERSEDIAAN & KEBUTUHAN & KETERSEDIAAN \\
\hline Cibeber & 49 & 30 & 38 & 26 & 13 & 13 & 13 & 11 \\
\hline Cilegon & 37 & 23 & 29 & 17 & 10 & 5 & 10 & 4 \\
\hline Ciwandan & 39 & 16 & 30 & 21 & 10 & 17 & 10 & 14 \\
\hline Citangkil & 63 & 28 & 49 & 30 & 16 & 14 & 16 & 13 \\
\hline Grogol & 37 & 15 & 29 & 16 & 10 & 7 & 10 & 4 \\
\hline Jombang & 55 & 38 & 43 & 35 & 14 & 13 & 14 & 13 \\
\hline Pulomerak & 37 & 12 & 29 & 26 & 10 & 7 & 10 & 2 \\
\hline Purwakarta & 32 & 17 & 25 & 24 & 8 & 8 & 8 & 9 \\
\hline TOTAL & 350 & 179 & 273 & 195 & 91 & 84 & 91 & 70 \\
\hline
\end{tabular}

Sumber: Hasil Analisis, 2020

Berdasarkan tabel kebutuhan dan ketersediaan sarana pendidikan di Kota Cilegon Tahun 2019, selanjutnya menghitung Persentase Ketersediaan Sarana Pendidikan, dengan hasil sebagaimana ditampilkan dalam Gambar 1 seperti dibawah ini:

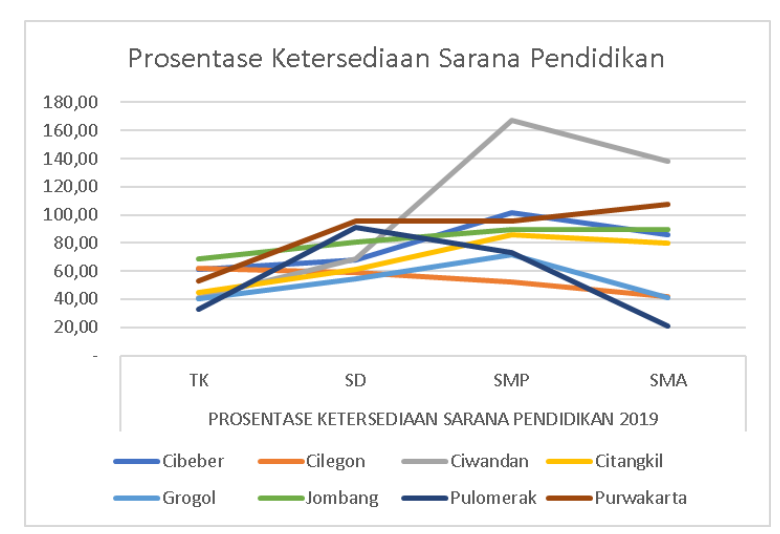

Gambar 1 Persentase Ketersediaan Sarana Pendidikan

Gap yang harus dipenuhi di setiap jenjang sekolah per kecamatan, dihitung berdasarkan selisih antara kebutuhan dan ketersediaan Sarana Pendidikan di Kota Cilegon, ditampilkan dalam tabel berikut:

Tabel 3. GAP Kebutuhan dan Ketersediaan Sarana Pendidikan

\begin{tabular}{|l|c|c|c|c|}
\hline \multirow{2}{*}{ KECAMATAN } & \multicolumn{4}{|c|}{ GAP ANTARA KEBUTUHAN DAN KETERSEDIAAN } \\
\cline { 2 - 5 } & TK & SD & SMP & SMA \\
\hline Cibeber & 19 & 12 & 0 & 2 \\
\hline Cilegon & 14 & 12 & 5 & 6 \\
\hline Ciwandan & 23 & 9 & -7 & -4 \\
\hline Citangkil & 35 & 19 & 2 & 3 \\
\hline Grogol & 22 & 13 & 3 & 6 \\
\hline Jombang & 17 & 8 & 1 & 1 \\
\hline Pulomerak & 25 & 3 & 3 & 8 \\
\hline Purwakarta & 15 & 1 & 0 & -1 \\
\hline Total & $\mathbf{1 7 1}$ & $\mathbf{7 8}$ & $\mathbf{7}$ & $\mathbf{2 1}$ \\
\hline
\end{tabular}

Sumber : Hasil Analisis, 2020

\section{b. Analisis Kebutuhan Sarana Pendidikan Berdasarkan Jumlah Anak Usia Sekolah}

Dalam analisis ini, agar perhitungan kebutuhan sarana pendidikan lebih akurat, maka penulis mencoba menghitung gap kebutuhan gedung sekolah berdasarkan jumlah anak dalam rentang usia tertentu yang tidak sekolah yang harus dipenuhi sarana pendidikannya. Adapun hasil perhitungannya adalah sebagaimana dalam tabel berikut : 
Tabel 4 Perhitungan Kebutuhan Jumlah Sekolah

\begin{tabular}{|c|c|c|c|c|c|c|c|c|c|c|}
\hline \multirow[b]{2}{*}{ USIA } & \multirow{2}{*}{\begin{tabular}{|l|} 
JUMLAH \\
ANAK USIA \\
SEKOLAH
\end{tabular}} & \multicolumn{4}{|c|}{ JUMLAH ANAK YANG BERSEKOLAH } & \multirow{2}{*}{$\begin{array}{c}\text { JUMLAH ANAK } \\
\text { YANG TIDAK } \\
\text { SEKOLAH }\end{array}$} & \multirow{2}{*}{$\begin{array}{l}\text { SEKOLAH } \\
\text { YANG } \\
\text { TERSEDIA }\end{array}$} & \multirow{2}{*}{$\begin{array}{l}\text { GAP JUMLAH } \\
\text { SEKOLAH }\end{array}$} & \multirow{2}{*}{$\begin{array}{l}\text { TOTAL } \\
\text { JUMLAH } \\
\text { SEKOLAH }\end{array}$} & \multirow{2}{*}{$\begin{array}{l}\text { PROSENTASE } \\
\text { KETERSEDIAAN }\end{array}$} \\
\hline & & TK & SD & SMP & SMA & & & & & \\
\hline 4-6 (TK) & 24.831 & 8.938 & 6.155 & - & 0 & 5.211 & 179 & 116 & 295 & 60,72 \\
\hline $7-12(S D)$ & 45.576 & - & 43.386 & 1.830 & 0 & 360 & 195 & 2 & 197 & 98,98 \\
\hline $13-15$ (SMP) & 21.247 & - & 307 & 18.757 & 1.520 & 663 & 84 & 2 & 86 & 97,85 \\
\hline 16-18 (SMA) & 21.381 & - & - & 2.402 & 15.578 & 3.401 & 70 & 9 & 79 & 88,11 \\
\hline $19-22$ & & & & & 1.995 & & & & & \\
\hline
\end{tabular}

Sumber : Hasil Analisis, 2020 (berdasarkan data Profil Dindik 2019)

\section{c. Analisis Hubungan antara Ketersediaan Sarana Pendidikan dengan APK}

Analisis hubungan antara Persentase Ketersediaan Sarana Pendidikan dengan APK, dilakukan untuk jenjang pendidikan TK, SD dan SMP. Pada jenjang SMA tidak penulis analisis, dikarenakan tidak tersedia data APK SMA per kecamatan. Adapun persentase ketersediaan sarana pendidikan yang digunakan untuk analisis menggunakan hasil analisis berdasarkan jumlah penduduk sesuai standar SNI 03-1733-2004.

Tabel 5. Perbandingan antara Persentase Ketersediaan Sarana Pendidikan dengan APK

\begin{tabular}{|c|c|c|c|c|c|c|}
\hline \multirow[b]{2}{*}{ KECAMATAN } & \multicolumn{2}{|c|}{ TK } & \multicolumn{2}{|c|}{ SD } & \multicolumn{2}{|c|}{ SMP } \\
\hline & $\begin{array}{c}\text { PROSENTASE } \\
\text { KETERSEDIAAN } \\
\text { SARANA } \\
\text { PENDIDIKAN }\end{array}$ & APK & $\begin{array}{c}\text { PROSENTASE } \\
\text { KETERSEDIAAN } \\
\text { SARANA } \\
\text { PENDIDIKAN }\end{array}$ & APK & $\begin{array}{c}\text { PROSENTASE } \\
\text { KETERSEDIAAN } \\
\text { SARANA } \\
\text { PENDIDIKAN }\end{array}$ & APK \\
\hline Cibeber & 60,9 & 60,30 & 67,58 & 112,79 & 101,37 & 162,58 \\
\hline Cilegon & 62,2 & 64,91 & 58,84 & 89,29 & 51,92 & 96,66 \\
\hline Ciwandan & 41,1 & 60,74 & 68,98 & 101,93 & 167,52 & 121,71 \\
\hline Citangkil & 44,6 & 48,30 & 61,19 & 101,08 & 85,66 & 80,29 \\
\hline Grogol & 40,0 & 50,11 & 54,62 & 84,96 & 71,69 & 118,29 \\
\hline Jombang & 68,5 & 61,38 & 80,73 & 117,84 & 89,96 & 80,80 \\
\hline Pulomerak & 32,8 & 44,22 & 90,98 & 121,68 & 73,49 & 87,07 \\
\hline Purwakarta & 52,7 & 69,91 & 95,28 & 152,83 & 95,28 & 138,17 \\
\hline
\end{tabular}

Sumber : Hasil Analisis, 2020

Berdasarkan Tabel Perbandingan antara Persentase Ketersediaan Sarana Pendidikan dengan APK, selanjutnya dianalisis dengan menggunakan regresi linear sederhana untuk mengukur seberapa besar hubungan antara persentase ketersediaan sarana pendidikan dengan APK berdasarkan jenjang pendidikan, sebagaimana terlihat dalam Gambar 2, 3 dan 4.

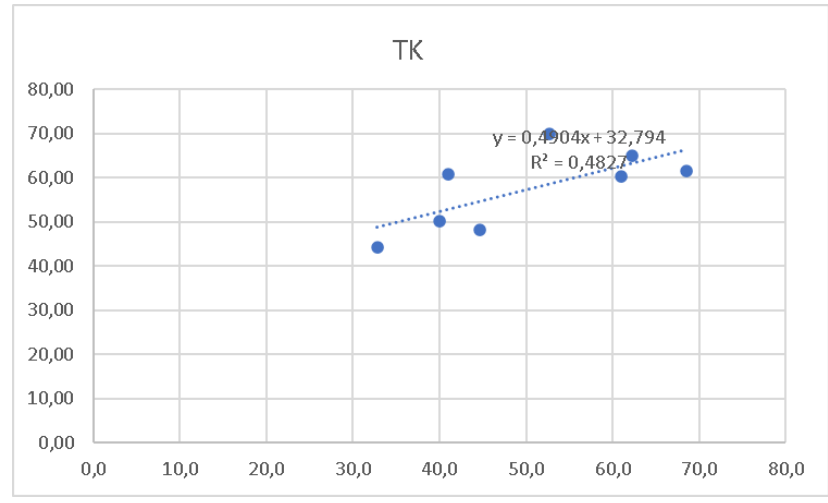

Gambar 2 Analisis Regresi TK 


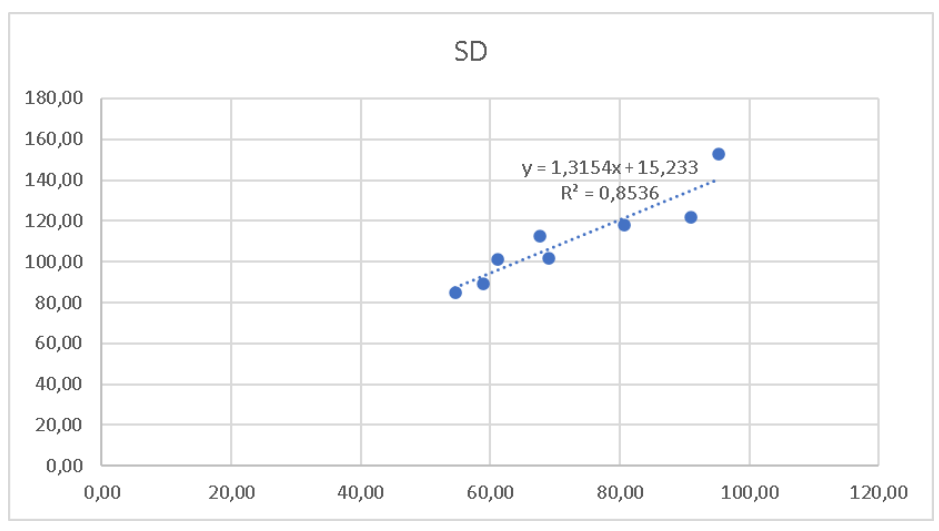

Gambar 3 Analisis Regresi SD

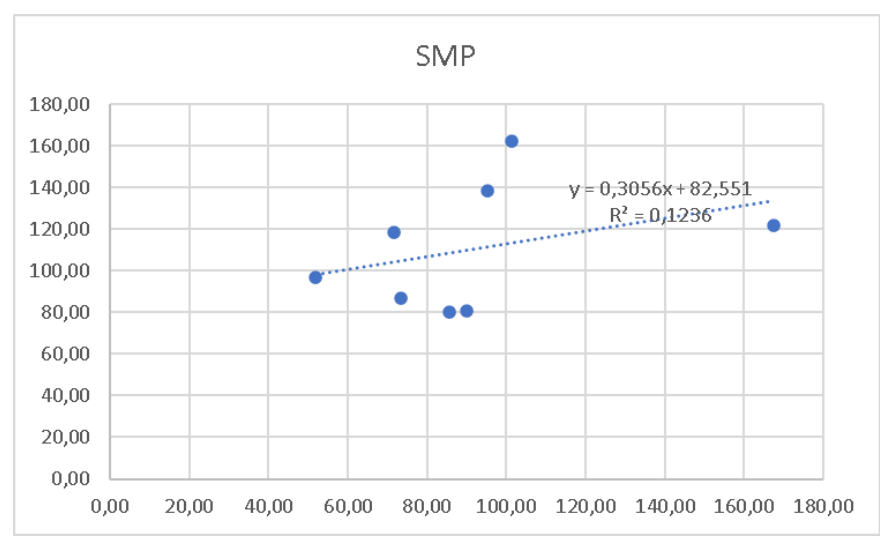

Gambar 4 Analisis Regresi SMP

Berdasarkan analisis kebutuhan jumlah bangunan sekolah menurut jumlah penduduk sesuai SNI-03-173-2004 sebagaimana ditunjukkan pada tabel 2 di Kota Cilegon masih terdapat gap antara kebutuhan dan ketersediaan bangunan sekolah baik tingkat TK, SD, SMP maupun SMA. Ketersediaan sarana bangunan sekolah TK pada separuh wilayah Cilegon masih jauh dari jumlah standar. Ketersediaan bangunan sekolah SD pada sebagian besar wilayah Cilegon sudah memadai, namun terdapat 2 dari 8 wilayah kecamatan yang masih dibawah $60 \%$ yaitu Kecamatan Cilegon dan Kecamatan Grogol. Sedangkan ketersediaan bangunan sekolah SMP yang masih dibawah 60 \% hanya tinggal di 1 wilayah kecamatan, yaitu Kecamatan Cilegon. Adapun ketersediaan bangunan sekolah SMA yang belum mencapai 50 \% terdapat di 3 wilayah kecamatan, yaitu Kecamatan Cilegon, Kecamatan Grogol dan Kecamatan Pulomerak.

Gambar 1 menunjukkan bahwa ada 1 wilayah kecamatan yaitu Ciwandan yang ketersediaan sarana pendidikan SMP dan SMA-nya paling tinggi, hingga melebihi $100 \%$. Hal ini kemungkinan terjadi karena Kecamatan Ciwandan lebih luas dibandingkan dengan wilayah kecamatan lainnya. Di samping itu, tingkat kepadatan penduduk di wilayah ini paling rendah di Kota Cilegon. Dengan kondisi tersebut maka ketersediaan lahan untuk pembangunan sekolah masih memadai. Hal ini selaras dengan hasil penelitian Farawoman, dkk (2020) yang menyatakan bahwa daerah yang memiliki kepadatan penduduk tinggi memiliki jumlah unit SD dan SMP yang tidak memadai. Demikian juga Tahir dan Nahdatunnisa (2020) menyatakan bahwa jumlah dan layanan sarana Pendidikan formal dipengaruhi oleh oleh laju pertambahan penduduk.

Persentase ketersediaan sarana pendidikan SMA hampir separuhnya belum mencapai $50 \%$, bahkan terdapat 1 wilayah kecamatan yang baru mencapai 21 \% yaitu Kecamatan Pulomerak. Hal ini kemungkinan disebabkan kondisi morfologi Kecamatan Pulomerak berupa pegunungan yang sulit diakses alat transportasi umum (Pulungan, 2019), serta memiliki keterbatasan ketersediaan air 
bersih. Selain itu, adanya kecenderungan siswa SMA untuk sekolah diluar wilayah tempat tinggalnya.

Hasil analisis kebutuhan jumlah sekolah berdasarkan jumlah anak usia sekolah, terlihat bahwa gap antara kebutuhan dan ketersediaan gedung sekolah tidak terlalu besar, bahkan Persentase ketersediaan sarana pendidikan atau gedung sekolah untuk jenjang SD, SMP dan SMA sudah melebihi 80 \%. Sedangkan Persentase ketersediaan sarana pendidikan TK diatas 60 \%. Adanya perbedaan hasil perhitungan kebutuhan sarana pendidikan berdasarkan jumlah penduduk dan jumlah anak usia sekolah, diduga karena sarana pendidikan yang sudah ada, memiliki ruang kelas yang melebihi standar minimum sehingga dapat menampung siswa lebih banyak. Selain itu, kemungkinan hal ini terjadi karena adanya perbedaan standar antara SNI 03-1733-2004 dengan Permendikbud 23 tahun 2013, terkait dengan jarak maksimal sekolah (Lestari dan Kusumo, 2015), serta jumlah rombongan belajar dalam satu kelas (Perdana, 2018).

Hasil analisis regresi linear hubungan Persentase ketersediaan sarana pendidikan dengan APK jenjang TK sebagaimana dalam Gambar 2, menunjukkan bahwa kedua variabel memiliki hubungan tetapi tidak terlalu signifikan. Hal ini menunjukkan bahwa nilai APK TK tidak dominan dipengaruhi oleh ketersediaan sarana pendidikan TK, tetapi kemungkinan juga dipengaruhi oleh faktor lain, hal ini disampaikan juga oleh Rohmani (2020). Nilai APK TK di Kota Cilegon yang masih rendah, diduga disebabkan karena motivasi orang tua untuk menyekolahkan anaknya ke sekolah TK masih kurang. Kurangnya motivasi ini dapat disebabkan karena terbatasnya pemahaman orang tua terhadap pentingnya pendidikan anak usia dini (Ayuna, 2017), serta masih adanya anggapan jika anak teralu dini mengenyam bangku sekolah, maka akan mengalami kebosanan dalam menuntut ilmu (Etivali dan Kurnia, 2019). Persentase ketersediaan sarana pendidikan TK di Kota Cilegon secara total baru mencapai 51,18 \%, hal ini berpengaruh terhadap tingkat motivasi orang tua untuk menyekolahkan anaknya ke jenjang TK. Oleh karena itu, walaupun hubungan kedua variabel ini tidak terlalu signifikan tetapi tetap memiliki hubungan yang moderat, sehingga ketersediaan sarana pendidikan TK harus ditingkatkan untuk meningkatkan APK jenjang TK.

Dalam Gambar 3 dapat dilihat bahwa berdasarkan hasil analisis, Persentase ketersediaan sarana pendidikan SD memiliki hubungan yang signifikan dengan APK. Hal ini menunjukkan bahwa dengan peningkatan jumlah sarana pendidikan SD akan meningkatkan APK SD. Nilai APK SD di Kota Cilegon yang cukup tinggi menunjukkan bahwa kesadaran masyarakat untuk menempuh pendidikan dasar sudah tinggi pula (Amaliah, 2015). Hal ini didukung dengan ketersediaan sarana pendidikan SD di Kota Cilegon yang sudah memadai, diatas $70 \%$.

Hasil analisis regresi linear antara Persentase ketersediaan sarana pendidikan dengan APK jenjang SMP di Kota Cilegon, sebagaimana dalam gambar 4, menunjukkan bahwa kedua variabel tersebut tidak memiliki hubungan yang signifikan. Ketersediaan sarana SMP tidak mempengaruhi nilai APK SMP. Berdasarkan Tabel 5, nilai APK tingkat SMP cukup tinggi, bahkan di Kecamatan Cilegon, walaupun Persentase ketersediaan sarana pendidikan SMP hanya 51\% tetapi APK SMP-nya mencapai $96,66 \%$. Hal ini menunjukkan bahwa kesadaran masyarakat untuk menempuh pendidikan dasar cukup tinggi, sehingga sekalipun ketersediaan sarana pendidikan SMP di wilayahnya terbatas, tetapi mereka tetap menyekolahkan anaknya ditempat lain. Kecenderungan ini diduga juga dipengaruhi oleh nilai religi masyarakat di Kota Cilegon yang cukup kuat sehingga banyak orangtua yang menyekolahkan anaknya ke pondok pesantren (Nugroho, 2016) ataupun boarding school di luar Kota Cilegon. Hal inilah yang diperkirakan menyebabkan analisis hubungan antara persentase ketersediaan sarana pendidikan dan APK tingkat SMP tidak signifikan.

\section{KESIMPULAN}

Ketersediaan sarana pendidikan di Kota Cilegon berdasarkan jumlah penduduk (SNI 03-17332004) rata-rata telah cukup memadai, dimana Persentase ketersediaan sarana pendidikan sudah melebihi $70 \%$ kecuali untuk jenjang TK. Persentase ketersediaan sarana pendidikan di Kota Cilegon pada jenjang TK baru terpenuhi sebesar $51,18 \%$, sehingga masih perlu ditingkatkan. Ketersediaan sarana pendidikan jenjang SD terpenuhi sebesar 71,36 \%, jenjang SMP terpenuhi sebesar 92,22\% dan jenjang SMA terpenuhi sebesar 76,85 \%. Sedangkan ketersediaan sarana pendidikan di Kota 
Cilegon yang dihitung berdasarkan jumlah anak usia sekolah, pada jenjang TK terpenuhi sebesar $60,72 \%$, jenjang SD terpenuhi sebesar $98,98 \%$, jenjang SMP terpenuhi sebesar $97,85 \%$, dan jenjang SMA terpenuhi sebesar $88,11 \%$.

Hubungan antara Persentase ketersediaan sarana pendidikan berdasarkan jumlah penduduk dan APK di Kota Cilegon menunjukkan bahwa kedua variabel saling mempengaruhi, dimana hubungan antara ketersediaan sarana pendidikan TK terhadap APK memiliki pengaruh yang moderat, dengan nilai koefisien regresi $R^{2}$ sebesar 0,482 . Hubungan antara ketersediaan sarana pendidikan SD terhadap APK memiliki pengaruh yang signifikan, dengan nilai koefisien regresi $R^{2}$ sebesar 0,854 , sedangkan ketersediaan sarana Pendidikan berdasarkan jumlah penduduk terhadap APK pada jenjang pendidikan SMP di Kota Cilegon tidak memiliki hubungan yang signifikan, dengan nilai koefisien regresi $R^{2}$ sebesar 0,124 .

\section{DAFTAR PUSTAKA}

Amaliah, D. (2015). Pengaruh Partisipasi Pendidikan terhadap Persentase Penduduk Miskin. Jurnal Ilmiah Kependidikan Vol. 2 No. 3, hal 231-239

Ashari, B.H., dkk. (2017). Analisis Deskriptif dan Tabulasi Silang pada Konsumen Online shop di Instagram (Studi Kasus 6 Universitas di Kota Surabaya). Jurnal Sains dan Seni ITS Vol. 6 No. 1, hal 17-21

Ayuna, Q. (2017). Motivasi Orang Tua Memasukkan Anaknya pada Kelompok Bermain. Jurnal Ilmiah Pendidikan Anak Vol. 1 No. 1, hal 69-91

Dini, A. (2015). Pengaruh Partisipasi Pendidikan terhadap Persentase Penduduk Miskin. Jurnal Ilmiah Kependidikan Vol. 2 No. 3 Nopember 2015, hal 231-239

Etivali, A.U.A., dan Kurnia, A.M.B. (2019). Pendidikan pada Anak Usia Dini. Jurnal: Penelitian Medan Agam Vol. 10 No. 2, hal 212-237

Faisol, dkk. (2016). Peramalan Aids Menggunakan Regresi Linear Sederhana. Zeta-Math Journal Vol. 2 No. 1, hal 22-26

Farawoman, Y., dkk. (2020). Kajian Ketersediaan Sarana Pendidikan di Kawasan Perkotaan Amurang. Jurnal Spasial Vol. 7 No. 1, hal 1-10

Imron, M.I.A. (2018). Pengaruh Kepuasan Pelanggan terhadap Minat Beli Ulang Makanan di Rumah Makan Ayam Bakar Wong Solo Alauddin Kota Makassar. Jurnal Profitability Fakultas Ekonomi dan Bisnis Vol. 2 No. 1, hal 50-64

Istiqomah, A., dkk. (2018). Analisis Partisipasi Pendidikan pada Masyarakat Miskin Dusun Gumuk Limo Desa Nogosari Kecamatan Rambipuji Kabupaten Jember. Jurnal Pendidikan Ekonomi Vol. 12 No. 2, hal 227-235

Kurnia, D.C., dkk. (2015). Atikan UNPAD: Upaya Peningkatan Partisipasi dan Penyelesaian Sekolah Tingkat Dasar dan Menengah di Pedesaan Jawa Barat. Dharmakarya: Jurnal Aplikasi Ipteks untuk Masyarakat Vol. 4 No. 1, hal 4-9

Lestari, S.A., dan Kusumo, H. (2015). Perbandingan Variasi Jarak Temupuh ke Sekolah terhadap Prestasi Belajar IPA Siswa Kelas VII SMP Muhammadiyah 2 Kalibawang. Jurnal Bioedukatika Vol. 3 No. 1, hal 33-36

Melati, Z.R. (2018). Analisis Hubungan Ketersediaan Gedung Pendidikan SMA/Sederajat dengan Angka Partisipasi Kasar Di Kabupaten Wonosobo tahun 2017. Universitas Muhammadyah Surakarta (2018)

Nugroho, W. (2016). Peran Pondok Pesantren dalam Pembinaan Keberagaman Remaja. Mudarrisa, Jurnal Kajian Pendidikan Islah Vol. 8 No. 1, hal 89-116

Perdana, N.S. (2018). Analisis Capaian Rombongan Belajar di Provinsi Lampung Tahun 2018 dalam Upaya Implementasi Permendikbud Nomor 17 Tahun 2017. Jurnal Dewantara Vol. V, hal 116 
Pulungan, I. (2019). Implementasi Penentuan Zonasi dalam Pemerataan Pendidikan Siswa SMA Negeri 1 Kecamatan Sayur Matinggi Kabupaten Tapanuli Selatan. Jurnal Darul 'Ilmi Vol. 07 No. 01, hal 30-44

Putra, C.B.U. (2012). Kecerdasan Sosial Siswa Kelas Akselerasi. Educational Psychology Journal Vol. 1 No. 1, hal 37-43

Rohmani, N. (2020). Analisis Angka Partisipasi Kasar Pendidikan Anak Usia Dini (PAUD) di Seluruh Indonesia. Jurnal Obsesi: Jurnal Pendidikan Anak Usia Dini Vol.5 No. 1, hal 625-632

Sugarda, I.A. (2018). Upaya ke Arah Wajib Belajar 12 Tahun di Kabupaten Majalengka; Pendekatan Kebijakan. Jurnal Administrasi Pendidikan Vol.XXV No.2 Oktober 2018, hal 252-263

Tahir, M.A., dan Nahdatunnisa. (2020). Analisis Ketersediaan dan Pemenuhan Kebutuhan Prasarana dan Sarana Permukiman di Kawasan Perkotaan (Studi Kasus: Ketersediaan dan Kebutuhan Sarana Pendidikan di Kota Kendari). Jurnal Malige Arsitektur Vol. 2 No. 1, hal 20-29 